\title{
Diversity of phenological patterns of Handroanthus ochraceus (Bignoniaceae) in Costa Rica
}

\section{Jorge Arturo Lobo Segura}

Escuela de Biología, Universidad de Costa Rica, 11501-2060, San José, Costa Rica; jorge.lobo@ucr.ac.cr

\author{
Received 05-I-2018. Corrected 13-XII-2018. Accepted 17-I-2019.
}

\begin{abstract}
The study of phenological patterns in plant communities is of vital importance for understanding the temporal cycles of ecosystems, but there is little information on the diversity of phenological patterns that can occur at the intraspecific level, as well as the genetic or environmental factors causing this variation. In Handroanthus ochraceus, a deciduous tree species of neotropical dry forests, ecophysiological studies have proposed the release of water stress as the mechanism that triggers flowering and the sprouting of new leaves. During four years, I observed the cycles of leaf fall, flowering, fruiting, and new leaf production in seven Costa Rican sites that differed in their proximity to water courses and in soil moisture. Six were located in dry forest areas, and one in premontane forest. There were two general phenological patterns: the explosive, where trees depend on the first rains for floral anthesis and the expansion of leaf meristems, and the staggered pattern, with unsynchronized flowering at the beginning and middle of the dry season, independently of rainfall. Although this phenological variation has been previously recognized, the occurrence of these two patterns is not determined by the proximity of water courses, contradicting phenological models proposed for this tree species.
\end{abstract}

Key words: phenology; Handroanthus ochraceus; phenological cues; tropical dry forest; fragmentation effects, ENSO effects.

Lobo Segura, J. A. (2019). Diversity of phenological patterns of Handroanthus ochraceus (Bignoniaceae) in Costa Rica. Revista de Biología Tropical, 67(2) Suplemento, S149-S158.

In plants, the timing of phenological events can be determined by several immediate environmental or endogenous factors, whose detection and response by plants have been the product of evolutionary forces shaping phenological patterns, such as adaptations to water seasonality, light differences, pollination conditions, and availability of seed and fruitdispersal agents (that can be considered as ultimate or causal factors). Environmental cues, such as changes in soil and air humidity levels (Borchert, 1994a), temperature (Ashton, Givnish \& Appanah, 1988), photoperiod (Rivera et al., 2002), irradiance (Wright \& Van Schaik, 1994), and sporadic climatic events, as a drop in minimum temperatures (Sakai et al., 1999) have been mentioned as proximal causes triggering phenological events in tropical plants. In tropical dry forests with a marked dry season, changes in water availability due to variations in rainfall levels and soil moisture have been proposed as essential determinants, both proximal and ultimate, of the phenological patterns of various tree species in these ecosystems (Reich \& Borchert, 1984; Borchert, 1994b).

The dry forest tree species Handroanthus ochraceus (Cham.) Mattos (Grose \& Olmstead, 2007), formerly known as Tabebuia ochraceae (Gentry, 1992), is distributed from Honduras to Brazil and northern Argentina. In the province of Guanacaste, Costa Rica, populations of this species have been previously referred to as Tabebuia neochrysantha (Gentry, 1970) or 
T. ochraceae subsp. neochrysantha (Gentry, 1992). This tree is classified as a hardwood species with highly synchronized flowering and leaf budding. Flower anthesis and new leaf production depend on a decrease in water stress in the trunk and branches (Reich \& Borchert, 1982; Borchert, 1994a,b). Based on observations of its phenological patterns in dry and moist soils as well as artificial irrigation experiments in a population in the town of Cañas, Guanacaste Province, previous authors established that flower bud anthesis in this species occurs shortly after leaf fall in trees growing in moist soils, but only after the first rains of the wet season in trees growing in dry soils (Reich \& Borchert ,1982; Borchert, 1994a,b). It was proposed that the physiological basis of this phenological behavior was the requirement of increased water levels within the plant for the cellular expansion of the floral and vegetative meristems (Reich \& Borchert, 1982; Borchert, 1994a). For similar reasons, leaf fall can occur at the beginning of the dry season in dry sites, but it can be delayed until the mid-dry season in moister locations. However, the ecophysiological studies of the phenology of this species were made during one year at sites with different soil moisture contents, in a single geographical location within its distribution (Reich \& Borchert, 1982; Borchert, 1994a,b). More phenological studies in a greater geographic and temporal range, including populations in sites with different levels of proximity to water sources, are necessary to confirm the proposed phenological patterns for this species. These studies may reveal the presence of other environmental signals for the triggering of phenological events, in addition to changes of water potential inside the trees. Such diversity of phenological cues within a tree species has been proposed for other species of trees of the genus Handroanthus (Borchert, Meyer, Felger, \& Porter-Bolland, 2004).

To better understand the phenology of this characteristic species of the Mesoamerican tropical dry forest and to test the previous hypotheses, I analyzed the variation in phenological patterns of seven populations of
$H$. ochraceus in the dry forest of Guanacaste Province and in a premontane moist forest in the Central Valley of Costa Rica (El Rodeo Ranch) for four years. The populations are distributed across sites with different levels of precipitation, forest fragmentation and soil moisture conditions, making it possible to detect phenological changes associated with these environmental factors.

\section{MATERIALS AND METHODS}

Site selection: During 2014-2017, bi-weekly observations of populations of $H$. ochraceus distributed across seven sites in Guanacaste Province and San José were carried out during the dry season (December-April) and monthly during the wet season (MayNovember). The names of the sites and their geographic locations, local ecosystem (according to Holdridge \& Tosi, 1967), and proximity to water courses as well as the sample size for each site are presented in Table 1. The El Rodeo Ranch site is an ecosystem with higher annual rainfall levels $(\sim 2400 \mathrm{~mm})$ than the other tropical dry forest sites $(\sim 1600 \mathrm{~mm})$, but all sites have a marked dry season during December-April. Among the tropical dry forest sites (Guanacaste Province), two had greater soil moisture (located close to seasonal rivers or permanent streams), i.e., Lomas de Barbudal (Biological Reserve) and Playa Naranjo Valley; one had intermediate soil moisture with many trees located near seasonal streams and the rest are located further away on slopes (Horizontes Station); and two had dry soils because they were far from water courses and near roads and urban areas with higher temperatures and evaporation rates (Liberia-Santa Rosa Highway, Lomas de Barbudal Road). Although soil moisture levels throughout the year were not measured directly, Reich \& Borchert (1982) showed that proximity to water courses is a good predictor of soil moisture dynamics at the beginning of the dry season. Likewise, the vegetation near the sites with natural forest was examined to verify the presence of evergreen species typical of riparian sites of dry forests in 
TABLE 1

Location and habitat characteristics of the H. ochraceus (Bignoniaceae) populations studied to determine their phenological patterns in Costa Rica

\begin{tabular}{|c|c|c|c|c|c|}
\hline Site & $\begin{array}{l}\text { Geographical } \\
\text { coordinates }\end{array}$ & Ecosystem & State of conservation & $\begin{array}{l}\text { Water } \\
\text { Courses }\end{array}$ & $\begin{array}{l}\text { No. } \\
\text { trees }\end{array}$ \\
\hline $\begin{array}{l}\text { El Rodeo Ranch, } \\
\text { Villa Colón }\end{array}$ & $\begin{array}{l}9^{\circ} 54^{\prime} 21^{\prime \prime} \mathrm{N} \\
84^{\circ} 15^{\prime} 02^{\prime \prime} \mathrm{W}\end{array}$ & Pre-montane moist forest & $\begin{array}{l}\text { Agricultural area } \\
\text { with forest fragments }\end{array}$ & $\begin{array}{l}3 \text { trees near, } \\
\text { the rest far }(>50 \mathrm{~m}) .\end{array}$ & 32 \\
\hline $\begin{array}{l}\text { Liberia-Santa Rosa } \\
\text { Natl. Park Highway }\end{array}$ & $\begin{array}{l}10^{\circ} 38^{\prime} 44^{\prime \prime} \mathrm{N}, \\
85^{\circ} 27^{\prime} 25^{\prime \prime} \mathrm{W} \\
\text { to } \\
10^{\circ} 49^{\prime} 42^{\prime \prime} \mathrm{N}, \\
85^{\circ} 33^{\prime} 15^{\prime \prime} \mathrm{W}\end{array}$ & Tropical dry forest & $\begin{array}{l}\text { Grasslands and semi-urban } \\
\text { areas along a national highway }\end{array}$ & $\begin{array}{l}\text { Flat terrain, trees far } \\
\text { from water courses }\end{array}$ & 54 \\
\hline $\begin{array}{l}\text { Mirador Trail, } \\
\text { Santa Rosa Natl. Park }\end{array}$ & $\begin{array}{l}10^{\circ} 48^{\prime} 35^{\prime \prime} \mathrm{N} \\
85^{\circ} 38^{\prime} 34^{\prime \prime} \mathrm{W}\end{array}$ & Tropical dry forest & Forest inside a National Park & $\begin{array}{l}\text { Flat area in the top } \\
\text { of hills, away from } \\
\text { water courses }\end{array}$ & 25 \\
\hline Horizontes & $\begin{array}{l}10^{\circ} 43^{\prime} 18^{\prime \prime} \mathrm{N} \\
85^{\circ} 36^{\prime} 03^{\prime \prime} \mathrm{W}\end{array}$ & Tropical dry forest & $\begin{array}{l}\text { Forest inside a National Park, } \\
\text { mostly secondary growth }\end{array}$ & $\begin{array}{l}\text { Trees }<20 \mathrm{~m} \text { away } \\
\text { from intermittent } \\
\text { stream }\end{array}$ & 20 \\
\hline $\begin{array}{l}\text { Playa Naranjo Valley, } \\
\text { Santa Rosa Natl. Park }\end{array}$ & $\begin{array}{l}10^{\circ} 47^{\prime} 49^{\prime \prime} \mathrm{N} \\
85^{\circ} 39^{\prime} 05^{\prime \prime} \mathrm{W}\end{array}$ & Tropical dry forest & $\begin{array}{l}\text { Old-growth forest inside } \\
\text { a National Park }\end{array}$ & $\begin{array}{l}\text { Valley bottom, } \sim 50 \mathrm{~m} \\
\text { away from river }\end{array}$ & 7 \\
\hline $\begin{array}{l}\text { Lomas de Barbudal } \\
\text { (Biol. Reserve) }\end{array}$ & $\begin{array}{l}10^{\circ} 30^{\prime} 43^{\prime \prime} \mathrm{N} \\
85^{\circ} 22^{\prime} 30^{\prime \prime} \mathrm{W}\end{array}$ & Tropical dry forest & $\begin{array}{l}\text { Forest inside a National Park, } \\
\text { mostly riparian forest }\end{array}$ & $\begin{array}{l}\text { Trees }<20 \mathrm{~m} \text { away } \\
\text { from permanent river }\end{array}$ & 17 \\
\hline $\begin{array}{l}\text { Lomas de Barbudal } \\
\text { Road }\end{array}$ & $\begin{array}{l}10^{\circ} 31^{\prime} 25^{\prime \prime} \mathrm{N} \\
85^{\circ} 21^{\prime} 27^{\prime \prime} \mathrm{W}\end{array}$ & Tropical dry forest & Pastures & $\begin{array}{l}\text { Trees along road } \\
\text { between pastures }\end{array}$ & 9 \\
\hline
\end{tabular}

the wet sites, as well as the presence of a majority of deciduous species typical of non-riparian environments at sites classified as dry (Frankie, Baker, \& Opler, 1974; Borchert, 1994b). Thus, it was possible to compare the phenological patterns of $H$. ochraceus under different soil moisture regimes.

Tree selection: For the phenological observations, $H$. ochraceus individuals with diameters at breast height $(\mathrm{DBH})>15 \mathrm{~cm}$ were selected at each site. Identification of the individuals as $H$. ochraceus was based on the diagnostic characteristics of the species (Gentry, 1992), especially the underside of the densely tomentose, whitish-brownish leaves with stellate trichomes that almost conceal the leaf surface and a calyx with long trichomes $(7 \mathrm{~mm})$. Most trees had a DBH $<50 \mathrm{~cm}$, except for six large trees with DBH of approximately 50-60 $\mathrm{cm}$ : two in Playa Naranjo Valley, two along
El Mirador Trail, one along the Liberia-Santa Rosa Highway, and one in El Rodeo Ranch. Differences in the timing of leaf shedding and flowering between small and large trees were analyzed to verify possible ontogenetic effects on phenological patterns.

Phenological observations: During the observation dates, the presence of leaves (old or new), flower buds, open flowers and fruits was recorded for each individual using binoculars. Following the phenological quantification method of Fournier (1974), the percentage of the tree canopy covered by each phenophase (leaves, flowers, fruits, and flower buds) was determined. To obtain a frequency value for each phenophase in each population, the mean percentage of the crown of each tree covered by each phenophase for each population was obtained per census date. Final phenology values were expressed on a scale ranging from 
zero to one, where one equals $100 \%$ of the tree crowns covered by a phenological phase, and zero is the inverse.

All sites were monitored periodically over four consecutive years (2014-2017) except for El Rodeo Ranch, where observations were carried out over three years (2015-2017), and the sites near the Lomas de Barbudal National Park (road and forest), which were only observed during the last two years.

Climate data: The phenological patterns observed in each population were compared with the daily rainfall patterns, particularly with the days when heavy rains $(>10 \mathrm{~mm}$ or $>$ $20 \mathrm{~mm}$ ) started at each site. The daily rainfall levels during December-June in the study years were obtained from automatic meteorological stations of the National Meteorological Institute (IMN, 2015) located near the study sites. Weather data from the following stations were used: El Rodeo, Liberia International Airport, and Santa Rosa. The reference stations for each phenological observation site were as follows: Liberia-Santa Rosa Highway, Horizontes and Lomas de Barbudal (Liberia Airport Station), El Mirador Trail and Playa Naranjo Valley (Santa Rosa Station), and El Rodeo (El Rodeo Station).

\section{RESULTS}

In the studied populations $H$. ochraceus trees sheds their leaves progressively since the early dry season (December-January), produce flowers during the middle of this season (February-March) or at the beginning of the rainy season (May-June) (Fig. 1, Fig. 2), and develop fruits few weeks after flowering (data not shown). Because the changes in phenophase (leaves, flowers, and fruits) are limited to the dry season (December-May), only the mean crown coverage for each phenophase during the dry season months is presented (Fig. 1, Fig. 2).

Two general phenological patterns were found. The explosive pattern, also called "bigbang" by Gentry (1974), was observed in the four forest sites in protected areas (Mirador, Playa Naranjo Valley, Horizontes and Lomas de Barbudal-forest) and one site located in a pasture site (Lomas de Barbudal Road). In this pattern flowering was fully determined by the start of rains at the end of the dry season, with the precise date ranging between the end of April and the beginning of June, depending on the date of the first heavy rains $(>10 \mathrm{~mm})$. In 2015 , flowering was delayed until the beginning of June because of a longer dry season due to an El Niño (ENSO) episode (IMN, 2015). In these populations, trees flowered on all their branches, and leaves sprouted in lateral buds a few days after the first rains. Leaf falling began in December and was completed by the end of January. This event was not accompanied by flowering, which causes a long period ( five months) during which the trees crowns were devoid of vegetative and reproductive structures, except for dormant flower buds.

In the second flowering pattern (staggered pattern), which was observed in the most disturbed sites such as El Rodeo and Liberia Highway - Guanacaste, flowering was more progressive. Individuals were observed flowering from December to the end of April, and the number of flowering trees gradually increased during the dry season, reaching a peak in March-April, one to two months before the onset of rains. In these sites, it is possible to observe modular flowering in some individuals, where some branches produced flowers while other branches are in another phenological phase (bare or with leaves). In these populations, the completion of leaf fall is followed a few weeks later by flowering, preventing the presence of trees with bare crowns for a long time, as observed in trees with the explosive pattern. Interestingly, these two phenological patterns were stable within populations through the years. No change between years from an explosive pattern to a staggered pattern or viceversa was observed. Likewise, early flowering (before any episode of rain during the dry season) as late (after a rain, especially at the beginning of the rainy season) were observed in trees of different diametric categories (data not 

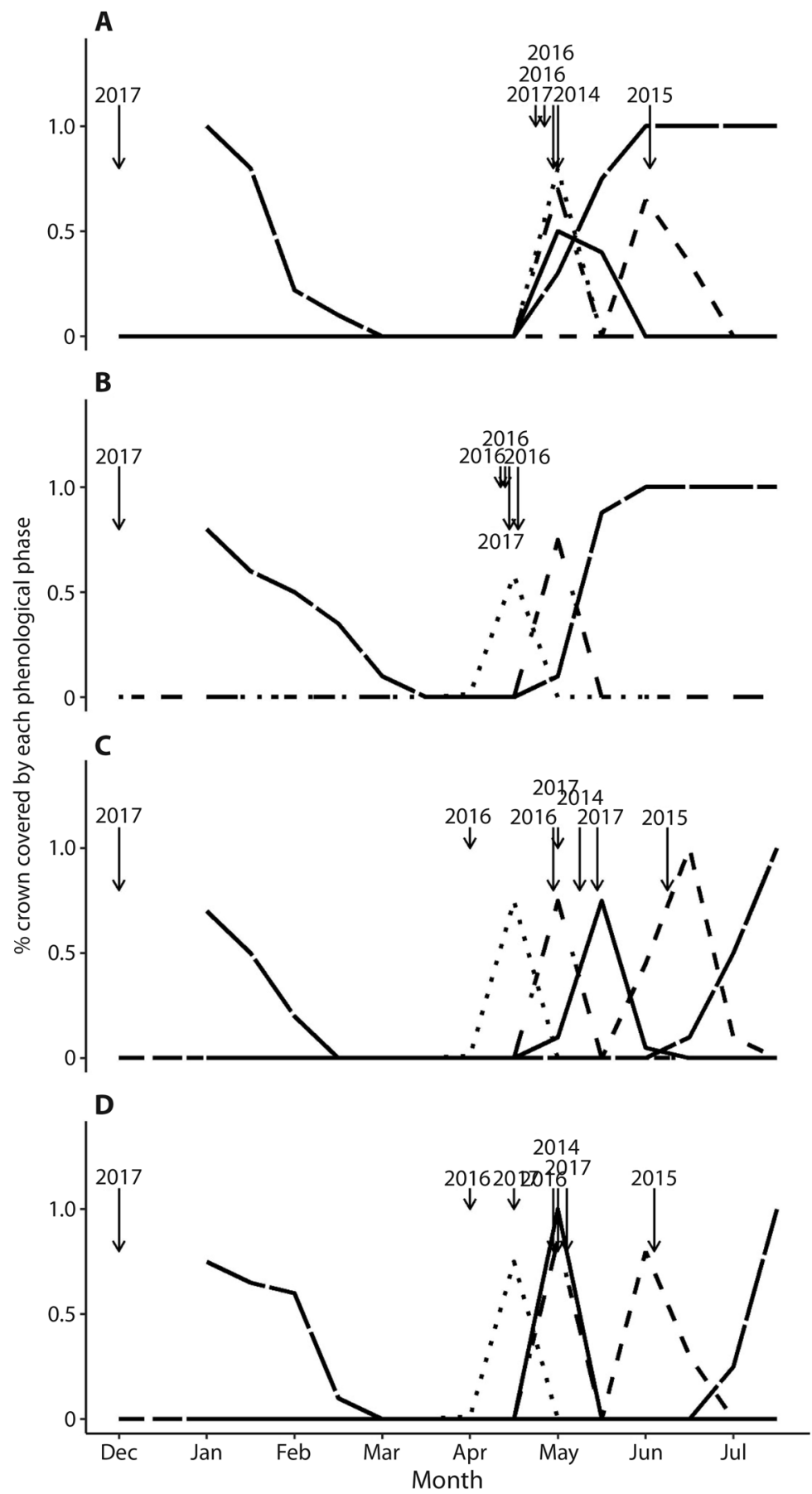

Fig. 1. Phenological patterns of Handroanthus ochraceus (Bignoniaceae), in the dry season and early wet season, from populations located in natural forest within protected areas during the dry and early wet seasons of 2014-2017, Guanacaste, Costa Rica: a) Horizontes, b) Lomas de Barbudal (Biological Reserve), c) Mirador Trail, Santa Rosa, and d) Playa Naranjo Valley, Santa Rosa. Data are mean crown coverage per population for flowers and leaves at two-week intervals. The arrows show the dates of the first rains $>10 \mathrm{~mm}$ per day (short arrows) or $>20 \mathrm{~mm}$ per day (long arrows) in each dry season. 

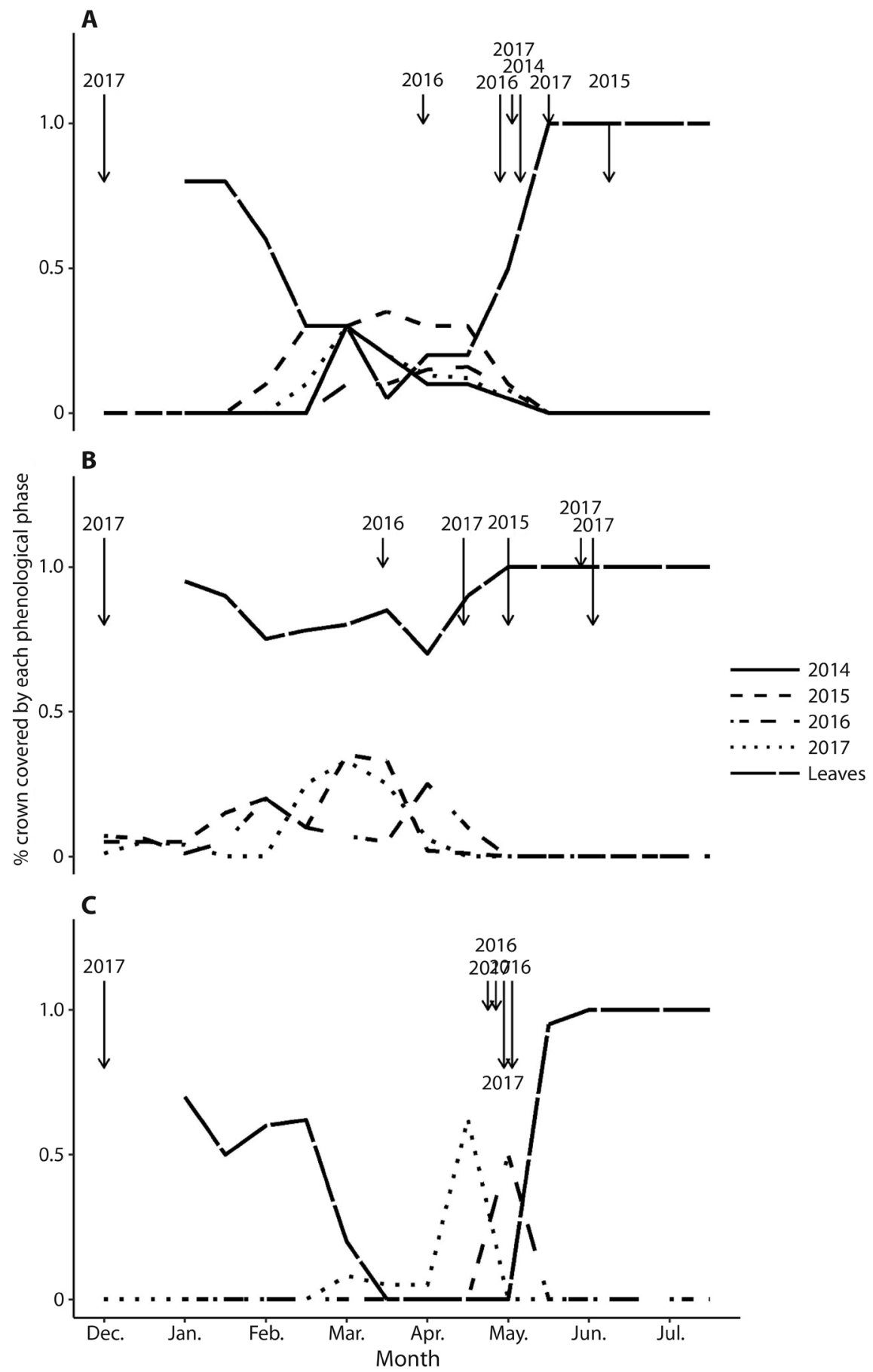

Fig. 2. Phenological patterns of Handroanthus ochraceus (Bignoniaceae), in the dry season and early wet season, from populations located in disturbed areas (pastures and forest fragments) during the dry and early wet seasons of 2014-2017, Costa Rica: a) Liberia-Sta Rosa Highway, b) El Rodeo Ranch, c) Lomas de Barbudal Road. Data are mean crown coverage per population for flowers and leaves at two-week intervals. The arrows show the dates of the first rains $>10 \mathrm{~mm}$ per day (short arrows) or $>20 \mathrm{~mm}$ per day (long arrows) in each dry season. 
shown). No relationship was observed between phenological pattern and tree diameter.

In some populations heavy rains in December or early January occurred in the years 2016 and 2017 (> $20 \mathrm{~mm}$ per day, Fig. 1, Fig. 2). However, the potential accumulation of higher levels of moisture from the previous rainy season does not change the flowering timing in these populations compared to the patterns observed in other years (Fig. 1, Fig. 2).

It should be noted that the two phenological patterns previously described are especially distinguished by the dates of flowering and consequent fruit ripening and new leaf budding. The dates of leaf fall are quite similar in both patterns, starting gradually at the end of December and completing in February, although with the staggered pattern, some early flowering individuals (December-January) can immediately replenish their leaves and have new leaves during the remainder of the dry season.

It was not observed a clear relationship between the proximity to water courses and their possible determination of soil moisture and the two observed phenological patterns. The population from Liberia - Santa Rosa Highway, despite most of the trees being located far from water courses in soils subjected to strong solar radiation, showed the staggered flowering pattern, and this was similar to the El Rodeo population, which was in a coffeegrowing area with most trees located far from water courses but with a shorter dry season (Fig. 2). The explosive flowering pattern was observed both in populations located far from water courses, including in El Mirador - Santa Rosa, as well as in populations near water courses (Lomas de Barbudal - forest, Horizontes and Playa Naranjo - Santa Rosa).

\section{DISCUSSION}

As observed by Frankie et al., (1974); Opler, Frankie, \& Baker (1976), and Reich \& Borchert (1982), H. ochraceus behaves like a deciduous tree, with many trees flowering in the dry season and with the onset of rains playing an important role in the synchronization of flowering in some populations. As also observed by those authors, there are intra- and interpopulation variations in the precise date of flowering, new leaf budding, and fruiting. Reich \& Borchert (1982) and Borchert (1994a) proposed that H. ochraceus trees flower when leaf fall (in moist soils) or the first rains (in dry soils) reduce the water stress and make water available for the opening of dormant flower buds and the production of leaf buds. The observations presented here show that the first rains do trigger the opening of dormant flower buds in some populations (explosive pattern), but this phenomenon occurs indiscriminately in populations in dry soils or in soils close to water courses, with presumed moister soils. Particularly revealing is the occurrence of the explosive phenological pattern in all trees in Lomas de Barbudal (forest) and Horizontes, where most of the trees have roots close to a permanent (Lomas) or seasonal (Horizontes) water course. If the phenological mechanisms proposed by Reich \& Borchert (1982) and Borchert (1994a) were correct, these trees should have shown early or staggered flowering. Similarly, the Liberia - Santa Rosa Highway population should have shown a phenology limited by dry soils, with flowering highly synchronized with the onset of rains, but we observed staggered flowering in this population.

The first rains of the rainy season function as a signal that synchronizes flowering in trees exhibiting the explosive phenological pattern, but the trees with the staggered pattern do not show such a high degree of flowering synchronization and instead produce new flowers and leaves long before the first rains in May-June. In these individuals, the process proposed by Borchert (1994a) for trees in moist areas seems to occur, where leaf fall is sufficient to trigger flowering, and these phenophases occur successively. However, this pattern of leaf fallsuccessive flowering was not restricted to trees in moist areas but was observed in populations in varying soil moisture conditions. 
Trees with either flowering pattern have dormant flower buds that are produced shortly after leaf budding and that remain on the tree during most of the wet season and the beginning of the dry season until their conversion into terminal flowers and lateral leaf buds, as observed by Reich \& Borchert (1982). This means that the differences between the two phenological patterns lie in the factors that trigger the anthesis of previously developed flower buds, not in factors that induce the production of flower buds.

One limitation of the results presented here is the lack of accurate soil moisture and root depth measurements, which could have revealed greater root capacity and/or moister soils in the Liberia-Santa Rosa Highway or El Rodeo populations and lower soil moisture or fewer deep roots in the populations located near water courses (Horizontes and Lomas). Although more accurate soil moisture measurements are required to confirm these observations, it is unlikely that soil moisture measurements will reveal moisture levels different from those predicted by the proximity to water courses since this parameter is the best indicator of soil moisture levels in tropical dry forests of Guanacaste, especially at a depth of $30 \mathrm{~cm}$ (Reich \& Borchert 1982). Another variable that was not studied was the type of soil. Edaphic variation among sites may modify the amount of water available for the trees, independently of the proximity of water sources.

Of the three populations located in fragmented forest and pasture areas, two showed the staggered flowering pattern. In fragmented, urban or agricultural areas, tree phenology can show changes in flowering intensity (Fuchs, Lobo, \& Quesada, 2003) or in both flowering intensity and phenological patterns (HerreríasDiego, Quesada, Stoner, \& Lobo, 2006). In Ceiba aesculifolia, trees in fragmented areas initiate flowering 10 to 20 days before trees in forests, depending on the year of study (Herrerías-Diego et al., 2006). As an effect of global warming or as a result of the higher temperatures in urban environments, phenological changes in leaf sprouting and flowering have been observed in temperate regions (Neil \& $\mathrm{Wu}, 2006)$. Greater insolation due to El Niño events enhanced flower production in a moist tropical forest in Panama (Wright \& Calderón, 2005), simulating the effect that open and fragmented environments can produce in flowering patterns. To propose that urban environments are affecting $H$. ochraceus populations in Costa Rica would imply accepting that the triggering of flowering and new leaf production in these populations is very possibly not subject to a single factor, such as soil or plant moisture, but to multiple environmental cues.

Lastly, there is the possibility of genetic differentiation in the mechanisms that trigger flowering among $H$. ochraceus populations in Costa Rica, as could occur due to the presence of cryptic species or species undergoing speciation. Differences among populations in important eco-physiological variables (water storage capacity, root depth, stomatal conductance, etc.) could explain the differences observed in the phenological patterns, and it should be noted that other populations of this species do not seem to show water limitations in flower anthesis development or new leaf production. Populations of $H$. ochraceus in the Brazilian cerrado (belonging to the subspecies ochraceus) show a floral phenology completely independent of the onset of rains during the dry season, as they flower in July-August at the midpoint of the long dry season in that biome (May-September) (Barros, 2001). Borchert et al. (2004) proposed that some populations of Handroanthus ochraceus or $H$. chrysantha can use the photoperiod as an environmental cue to trigger floral anthesis.

Although the existence of phenological variation in tropical plants at the intraspecific level has been widely documented, as illustrated by the high levels of phenological asynchrony observed in many species of tropical plants (SanMartin-Gajardo \& Morellato, 2003), there are few studies of the factors associated with intraspecific phenological heterogeneity, particularly the variation in phenological patterns between individuals and between populations of the same species (for example, see Dahlgren, 
von Zeipel, \& Ehrlen, 2007). In the case of H. ochraceus, a deciduous species of Neotropical dry forests and savannas, the present study demonstrates the presence of greater levels of variation in phenological pattern among populations than those described in previous eco-physiological studies of this species. This finding may affect analyses of phenological sensitivity in $H$. ochraceus and similar species to environmental factors as global warming, forest fragmentation and urbanization, which are often based on the assumption of uniform phenological behavior within plant species.

Ethical statement: the author declares that he agrees with this publication; that there is no conflict of interest of any kind; and that he followed all pertinent ethical and legal procedures and requirements. All financial sources are fully and clearly stated in the acknowledgements section. A signed document has been filed in the journal archives.

\section{ACKNOWLEDGEMENTS}

The author thanks Maria Marta Chavarría (Guanacaste Conservation Area) for help with field work, guidance, and phenological information as well as Róger Blanco for the use of facilities and guidance during visits within the Guanacaste Conservation Area. The National Meteorological Institute of Costa Rica (IMN) provided daily rainfall data from its automatic stations.

\section{RESUMEN}

Diversidad de patrones fenológicos de Handroanthus ochraceus (Cham.) Mattos (Bignoniaceae) en Costa Rica. El estudio de los patrones fenológicos en comunidades de plantas es de importancia vital para entender los ciclos temporales de los ecosistemas, pero hay poca información sobre la diversidad de patrones fenológicos que pueden ocurrir a nivel intraespecífico, así como sobre los factores genéticos o ambientales que explican esta variación. En Handroanthus ochraceus, una especie arbórea de bosques secos, estudios ecofisiológicos han propuesto la reducción del estrés hídrico como el mecanismo que dispara la floración y la brotación de hojas nuevas. Durante cuatro años se observaron los ciclos de caída de hojas, floración, fructificación y producción de hojas nuevas en esta especie en siete sitios en Costa Rica, que diferían en su proximidad a fuentes de agua y por consiguiente en los niveles de humedad del suelo. Dos patrones fenológicos generales fueron observados: el patrón explosivo, en el cual los árboles dependen de las primeras lluvias para desarrollar la antesis floral y la expansión de los meristemos foliares, y el patrón escalonado, en el cual los árboles pueden florecer en una forma modular durante el comienzo y parte media de la estación seca, en forma independiente de las lluvias. Aunque esta variación en patrones fenológicos ha sido previamente reconocida, en este estudio se demuestra por vez primera que esta variación no está necesariamente asociada a diferentes niveles de humedad del suelo, contradiciendo modelos fenológicos propuestos para esta especie de árbol.

Palabras clave: fenología; Handroanthus ochraceus; señales fenológicas; bosque tropical seco, efectos de la fragmentación, efecto ENSO.

\section{REFERENCES}

Ashton, P. S., Givnish, T. J., \& Appanah, S. (1988). Staggered flowering in the Dipterocarpaceae: new insights into floral induction and the evolution of mast fruiting in the aseasonal tropics. The American Naturalist, $132,44-66$.

Barros, M. G. (2001). Pollination ecology of Tabebuia aurea (Manso) Benth. \& Hook. and T. ochracea (Cham.) Standl. (Bignoniaceae) in Central Brazil cerrado vegetation. Brazilian Journal of Botany, 24, 255-261.

Borchert, R. (1994a). Induction of rehydration and bud break by irrigation or rain in decidous trees of a tropical dry forest in Costa Rica. Trees-Structure and Function, 8, 198-204.

Borchert, R. (1994b). Soil and stem water storage determine phenology and distribution of tropical dry forest trees. Ecology, 75, 1437-1449.

Borchert, R., Meyer, S. A., Felger, R. S., \& PorterBolland, L. (2004). Environmental control of flowering periodicity in Costa Rican and Mexican tropical dry forests. Global Ecology and Biogeography, 13, 409-425.

Dahlgren, J. P., von Zeipel, H., \& Ehrlén, J. (2007). Variation in vegetative and flowering phenology in a forest herb caused by environmental heterogeneity. American Journal of Botany, 94, 1570-1576.

Frankie, G. W., Baker, H. G., \& Opler, P. A. (1974). Comparative phenological studies of trees in tropical wet and dry forests in the lowlands of Costa Rica. Journal of Ecology, 62, 881-919. 
Fournier, L. A. (1974). Método cuantitativo para la medición de características fenológicas en árboles. Turrialba, 24, 422-423.

Fuchs, E. J., Lobo, J. A., \& Quesada, M. (2003). Effects of forest fragmentation and flowering phenology on the reproductive success and mating patterns of the tropical dry forest tree Pachira quinata. Conservation Biology, 17, 149-157.

Gentry, A. H. (1970). A revision of Tabebuia (Bignoniaceae) in Central America. Brittonia, 22, 246-264.

Gentry, A. H. (1974). Flowering phenology and diversity in tropical Bignoniaceae. Biotropica, 6, 64-68.

Gentry, A. H. (1992). Bignoniaceae: Part II (Tribe Tecomeae). Flora Neotropica, 25, 1-370.

Grose, S. O., \& Olmstead, R. G. (2007). Taxonomic revisions in the polyphyletic genus Tabebuia s.l. (Bignoniaceae). Systematic Botany, 32, 660-670.

Herrerías-Diego, Y., Quesada, M., Stoner, K. E., \& Lobo, J. A. (2006). Effects of forest fragmentation on phenological patterns and reproductive success of the tropical dry forest tree Ceiba aesculifolia. Conservation Biology, 20, 1111-1120.

Holdridge, L. R., \& Tosi, J. A. (1967). The life zone. Life Zone Ecology. San José, Costa Rica: Tropical Science Center.

Instituto Meterológico Nacional (IMN). (2015). Boletín del ENOS No. 79 (Informe 14). San José, Costa Rica. Recuperado de https://www.imn.ac.cr/ documents/10179/28160/\%23\%2079

Neil, K., \& Wu, J. (2006). Effects of urbanization on plant flowering phenology: a review. Urban Ecosystems, 9, 243-257.
Opler, P. A., Frankie, G. W., \& Baker, H. G. (1976). Rainfall as a factor in the release, timing, and synchronization of anthesis by tropical trees and shrubs. Journal of Biogeography, 3, 231-236.

Reich, P. B., \& Borchert, R. (1982). Phenology and ecophysiology of the tropical tree, Tabebuia neochrysantha (Bignoniaceae). Ecology, 63, 294-299.

Reich, P. B., \& Borchert, R. (1984). Water stress and tree phenology in a tropical dry forest in the lowlands of Costa Rica. Journal of Ecology, 72, 61-74.

Rivera, G., Elliott, S., Caldas, L. S., Nicolossi, G., Coradin, V. T., \& Borchert, R. (2002). Increasing day-length induces spring flushing of tropical dry forest trees in the absence of rain. Trees-Structure and Function, $16,445-456$.

Sakai, S., Momose, K., Yumoto, T., Nagamitsu, T., Nagamasu, H., Hamid, A. A., \& Nakashizuka, T. (1999). Plant reproductive phenology over four years including an episode of general flowering in a lowland dipterocarp forest, Sarawak, Malaysia. American Journal of Botany, 86, 1414-1436.

SanMartin-Gajardo, I., \& Morellato, P. C. (2003). Inter and intraspecific variation on reproductive phenology of the Brazilian Atlantic forest Rubiaceae: ecology and phylogenetic constraints. Revista de Biología Tropical, 51, 691-698.

Wright, S. J., \& Van Schaik, C. P. (1994). Light and the phenology of tropical trees. The American Naturalist, 143, 192-199.

Wright, S. J., \& Calderón, O. (2006). Seasonal, El Nino and longer term changes in flower and seed production in a moist tropical forest. Ecology letters, 9, 35-44. 